\title{
WEDM CUTTING OF INCONEL 718 NICKEL-BASED SUPERALLOY: EFFECTS OF CUTTING PARAMETERS ON THE CUTTING QUALITY
}

\author{
WEDM REZANJE NIKLJEVE SUPERZLITINE INCONEL 718: \\ VPLIV PARAMETROV REZANJA NA KVALITETO REZANJA
}

\author{
Ulaş Çaydaş, Mustafa Ay \\ University of Firat, Technology Faculty, Department of Mechanical Engineering, 23119 Elaziğ, Turkey \\ ucaydas@firat.edu.tr, ucaydas@gmail.com \\ Prejem rokopisa - received: 2015-01-26; sprejem za objavo - accepted for publication: 2015-02-19
}

doi:10.17222/mit.2015.026

\begin{abstract}
Investigations of the effects of machining parameters on the cutting quality of wire-electrical-discharge-machining (WEDM) cutting of an annealed Inconel 718 nickel-based superalloy are described in this paper. The cutting-quality characteristics considered are the kerf width, the recast-layer thickness and the surface roughness of the cut specimens. The essential process input parameters were identified as the pulse-on time, the pulse-peak current, and the injection pressure. The analysis of variance (ANOVA) technique was used to find the parameters affecting the cut quality. The regression analysis was used for the development of empirical models able to describe the effects of the process parameters on the quality of the WEDM cutting. The ANOVA results show that the pulse-on time and the pulse-peak current are significant variables affecting the surface roughness of wire-EDMed Inconel 718. The surface roughness, the kerf width and the recast layer of the test specimens increased as these two variables increased. The measured and modelled results were in good agreement with respect to the correlation coefficients $R_{\mathrm{a}}, R L T$ and $K \ddot{u}$.
\end{abstract}

Keywords: wire-electrical-discharge machining (WEDM), Inconel 718, recast layer, surface morphology, analysis of variance

V članku je opisana raziskava vplivov parametrov obdelave na kvaliteto reza, z žično elektroerozijo (WEDM) rezane žarjene nikljeve superzlitine Inconel 718. Upoštevane so bile karakteristike reza, kot je širina reza, debelina nataljenega sloja in hrapavost površine odrezanega vzorca. Ugotovljeno je, da so bistveni vhodni parametri procesa impulzi v času, tok vrha impulza in tlak vbrizgavanja. Za iskanje parametrov, ki vplivajo na kvaliteto reza je bila uporabljena tehnika analiza variance (ANOVA). Regresijska analiza je bila uporabljena za razvoj empiričnega modela, ki lahko opiše vpliv procesnih parametrov na kvaliteto WEDM rezanja. Rezultati iz ANOVE kažejo, da sta impulz v času in tok vrha impulza pomembni spremenljivki pri rezanju Inconela 718 z žično elektroerozijo. Hrapavost površine, širina zareze in debelina pretaljene plasti so naraščali pri preizkusnih vzorcih, če sta naraščali ti dve spremenljivki. Izmerjeni in modelirani rezultati so se dobro ujemali s korelacijskimi koeficienti $R_{\mathrm{a}}, R L T$ in $K \ddot{u}$.

Ključne besede: žična elektroerozija (WEDM), Inconel 718, pretaljena plast, morfologija površine, analiza variance

\section{INTRODUCTION}

Among nickel-based alloys, the superalloy Inconel 718 is one of the most important ones. Due to its high corrosion and high temperature resistance, it is commonly used in the space industry, in particular for the hot parts of plane, marine and industrial gas-turbine engines, rocket engines, nuclear reactors, submarines, pressure tanks, steam-turbine generators and other high-temperature applications. ${ }^{1-5}$ Despite this widespread use, it is classified as a difficult-to-machine material due to its unique characteristics such as low thermal conductivity, hardness, work hardening and the presence of abrasive carbide particles in its microstructure. ${ }^{3,6}$

Due to its thermal machining ability, wire-electrical-discharge machining (WEDM) has been an important manufacturing method as it provides effective solutions for machining difficult-to-machine materials, such as zirconium, nimonic, titanium, nickel, etc., that cannot be machined with traditional methods. ${ }^{7}$ Nonetheless, there are problems that remain to be solved such as the stresses that occur on the top layer where the material solidifies and in the formation of the heat-affected zone, micro-cracks, porosity, local hardness/softness, grain growth and small alloys that get transferred via dielectric fluids or the tool. ${ }^{8,9}$ For a complete and efficient WEDM, the machining parameters should be selected in accordance with the nature of the material.

Effects of the EDM-process parameters have been investigated. Kanlayasiri and Boonmung ${ }^{10}$ studied the effects of the pulse-on time, pulse-off time, pulse-peak current and wire tension (a wire electrode made of $\mathrm{Cu}-35 \%$ of mass fractions of $\mathrm{Zn}$; the wire was $\mathrm{KH}$ Sodick with $0.25 \mathrm{~mm}$ in diameter, tolerating a tension of up to 900 $\mathrm{MPa}$ ) on the surface roughness of the DC53 die steel. Kuriakose and Shunmugam ${ }^{11}$ investigated the characteristics of a WEDMed Ti6A14V surface. Gökler and Ozanözgü ${ }^{12}$ experimentally investigated the effects of the cutting parameters on the surface roughness in the WEDM process for the 1040, 2379 and 2738 steels. Miller et al. ${ }^{13}$ investigated the effects of the EDM process parameters, particularly the spark cycle time and 
spark-on time on thin cross-section cuts of the $\mathrm{Nd}-\mathrm{Fe}-\mathrm{B}$ magnetic material. Ramakrishnan and Karunamoorty ${ }^{14}$ developed a neural-network model in order to predict process outputs and to establish the optimum process parameters. Kang and $\mathrm{Kim}^{15}$ investigated the EDM characteristics of nickel-based heat resistant alloys; Hastelloy-X. Bai et al. ${ }^{16}$ developed electrical discharge surface alloying of superalloy Haynes 230 with Al and Mo. Aspinwall et al. ${ }^{17}$ developed 3D topographic maps of workpiece surfaces, microstructural and microhardness depth-profile data of Inconel 718.

So far, the most common workpiece materials used in the research of WEDM have been tool or die steels. Very little research was done to investigate the machinability of Inconel 718 with respect to WEDM. As a result, the effects of the machining parameters on the formation of the recast layer and the surface integrity during the WEDM of Inconel 718 remain to be elucidated in detail.

\section{EXPERIMENTAL WORK}

In this study, an annealed Inconel 718 nickel alloy with the AMD 5596 standard number was used. The chemical composition of this material is given in Table 1. WEDM cutting experiments were performed using an Accutex CNC WEDM machine. In the conducted experiments, a $\mathrm{CuZn}_{37}$ wire with a tensile strength of $900 \mathrm{~N} / \mathrm{m}^{2}$ and a diameter of $0.25 \mathrm{~mm}$ was used. In the experimental

Table 1: Chemical composition of Inconel 718

Tabela 1: Kemijska sestava Inconel 718

\begin{tabular}{|c|c|}
\hline Element & Composition $(w / \%)$ \\
\hline $\mathrm{Ni}$ & 53.60 \\
\hline $\mathrm{Cr}$ & 18.20 \\
\hline $\mathrm{Nb}$ & 5.06 \\
\hline $\mathrm{Mo}$ & 3.04 \\
\hline $\mathrm{Ti}$ & 0.97 \\
\hline $\mathrm{Al}$ & 0.44 \\
\hline $\mathrm{C}$ & 0.052 \\
\hline $\mathrm{B}$ & 0.003 \\
\hline $\mathrm{Si}$ & 0.10 \\
\hline $\mathrm{S}$ & $<0.002$ \\
\hline $\mathrm{P}$ & $<0.005$ \\
\hline $\mathrm{Fe}$ & Balance \\
\hline
\end{tabular}

Table 2: Machining parameters of WEDM in this study Tabela 2: Parametri obdelave $\mathrm{z}$ WEDM v tej študiji

\begin{tabular}{|l|c|c|c|}
\hline \multicolumn{1}{|c|}{ Cutting conditions } & \multicolumn{3}{c|}{ Settings } \\
\hline & Level 1 & Level 2 & Level 3 \\
\hline Pulsed current $(\mathrm{A})$ & 8 & 10 & 12 \\
\hline Gap voltage $(\mathrm{V})$ & 39 & - & - \\
\hline Pulse-on duration $(\mu \mathrm{s})$ & 5 & 7 & 9 \\
\hline Pulse-off duration $(\mu \mathrm{s})$ & 9 & - & - \\
\hline Wire tension $(\mathrm{N})$ & 10 & - & - \\
\hline Wire speed $(\mathrm{mm} / \mathrm{s})$ & 15 & - & - \\
\hline Flushing-circulation pressure $(\mathrm{MPa})$ & 1.27 & 1.47 & 1.76 \\
\hline Table-feed ratio $(\mathrm{mm} / \mathrm{min})$ & 10 & & \\
\hline
\end{tabular}

studies, the pulse current (A), pulse duration ( $\mu$ s) and dielectric flushing circulation pressure $(\mathrm{MPa})$ were chosen as variable parameters. With these cutting parameters and their levels, the Taguchi L9 experimental-design method was chosen as the basis and a total of 9 experiments were performed. The experimental parameters and their levels are provided in Table 2 and the sequence of the experiments is provided in Table $\mathbf{3}$.

Table 3: Experimental layout using an L9 orthogonal array Tabela 3: Eksperimentalna postavitev z uporabo L9 ortogonalne matrike

\begin{tabular}{|c|c|c|c|}
\hline Exp. No & $\begin{array}{c}\text { Pulsed current } \\
(\mathrm{A})\end{array}$ & $\begin{array}{c}\text { Pulse-on } \\
\text { duration }(\mu \mathrm{s})\end{array}$ & $\begin{array}{c}\text { Flushing } \\
\text { pressure }(\mathrm{MPa})\end{array}$ \\
\hline 1 & 8 & 5 & 1.27 \\
\hline 2 & 8 & 7 & 1.47 \\
\hline 3 & 8 & 9 & 1.76 \\
\hline 4 & 10 & 5 & 1.47 \\
\hline 5 & 10 & 7 & 1.76 \\
\hline 6 & 10 & 9 & 1.27 \\
\hline 7 & 12 & 5 & 1.76 \\
\hline 8 & 12 & 7 & 1.27 \\
\hline 9 & 12 & 9 & 1.47 \\
\hline
\end{tabular}

At the end of the experiments, the width of each cut was measured at five points along the cutting channel in order to determine the kerf widths. The measurements were performed using a profile-measuring microscope with a sensitivity of $0.002 \mathrm{~mm}$ (Model 98-0001, SCHERR-TUMICO, USA). In order to obtain the surface images, determining the microstructures of the surfaces and the heat-affected zones, the surface that was perpendicular and adjacent to the surface that was being machined was chosen and these surfaces were polished using 200-1200 mesh abrasive paper and a 3- $\mu \mathrm{m}$ diamond paste. The polished surfaces were etched with the electrolytic-etching method in a $50 \% \mathrm{HCl}$ and $50 \%$ methanol solution and at a $4.5 \mathrm{~V}$ voltage. ${ }^{1}$ The microstructural analysis of the specimens was done with a scanning electron microscope (SEM) and a three-dimensional atomic-force microscope (AFM). In order to determine the elements and phases on the machined surfaces, EDS (energy dispersive spectrograph) and XRD (X-ray diffraction) analyses were performed. Microhardness tests were conducted with a Leica Q500/L hardness tester using the Vickers scale. The surface roughness was obtained using a Mitutoyo Surftest SJ-201 portable device.

\section{RESULTS AND DISCUSSION}

\subsection{Effect of the cutting parameters on the surface structure}

In Figure 1, an image obtained after the cutting of the Inconel 718 nickel alloy with WEDM is shown. The surface is composed of spherical grains detached from the material that cannot be removed from the plain space with the liquid pressure, debris that melt and stick to the 


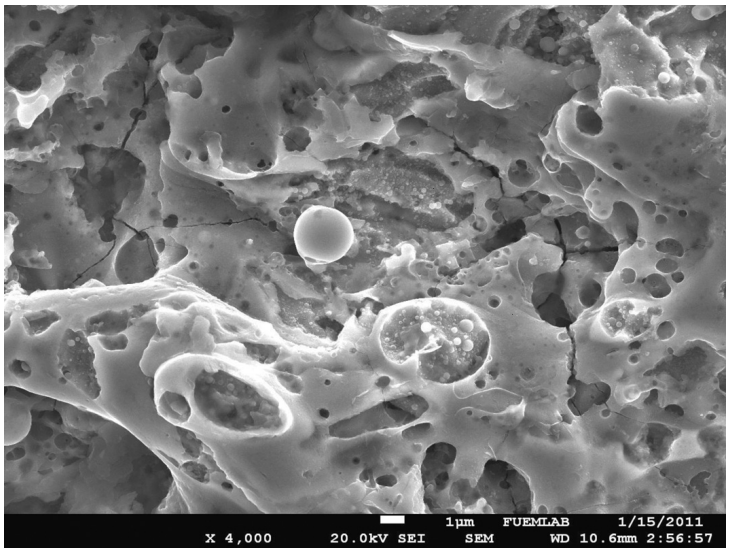

Figure 1: SEM micrograph of a WEDM-cut surface of Inconel 718 Slika 1: SEM-posnetek površine reza Inconel 718 po rezanju $\mathrm{z}$ WEDM

surface in drops, cracks, residues and randomly dispersed craters of various sizes. These craters are characterized as cavities formed by the spherical chips detached from the surface due to the effect of the sparks between the wire and the workpiece during the machining. In terms of the surface appearance, it was determined that the densities of the machined surfaces are similar, whereas the densities of the craters and hills on the surface are different, depending on the variations in the current and pulse duration.

Surface images of the specimens cut under different currents, pulse durations and fluid-circulation pressures are seen on Figure 2. As can be seen, when the strength of the current is constant, the surface gets rougher as the pulse duration increases. The pulse duration is the time

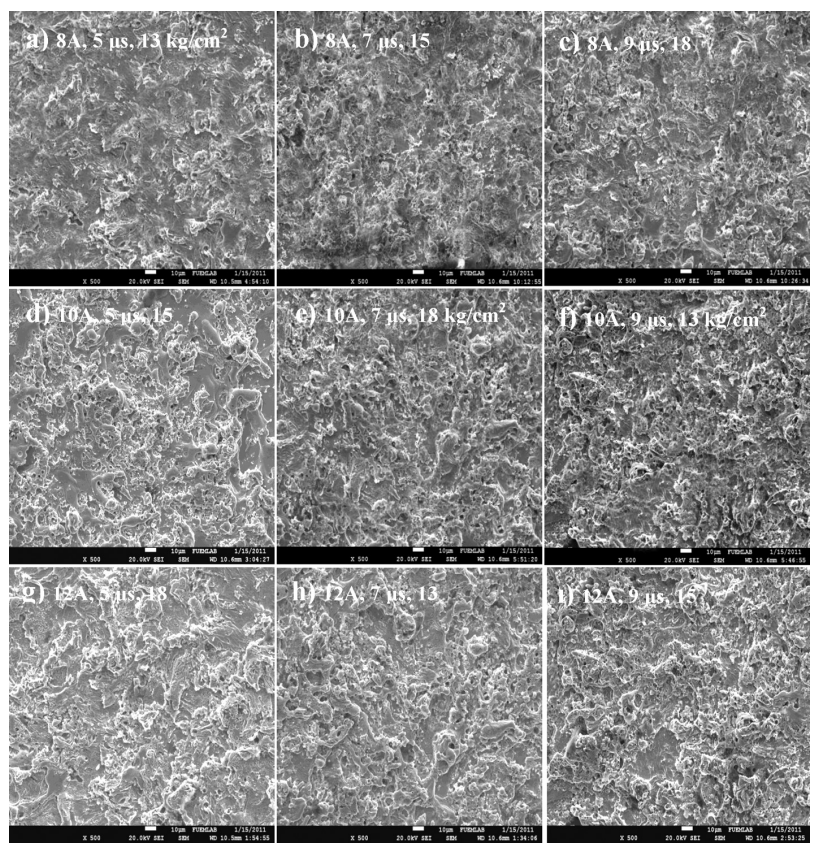

Figure 2: SEM micrographs of a surface WEDM-processed under different machining conditions

Slika 2: SEM-posnetki z WEDM obdelane površine pri različnih pogojih obdelave duration of the discharge applied to the wire electrode. In other words, it is the time of the spark discharge that forms between the wire and the workpiece. Therefore, an increase in the pulse duration leads to an increased transfer of heat onto the surface of the workpiece and a formation of larger craters on the surface of the workpiece. Similarly, the surface was observed to deteriorate also with an increased current.

An increase in the current intensity leads to a more intense energy discharge to the workpiece surface; thus, more chips detach from the surface. The increase in the amount of detached chips from the surface, at the same time, deteriorates the surface roughness. ${ }^{18}$ The results of the experiments show that the liquid-circulation pressure had little effect on the surface structure. Similarly, previous studies indicate that while the surface roughness increases with the increasing current and pulse duration, and wire fractures are prevented using an appropriate liquid-circulation pressure, the effect of the liquid-circulation pressure on the surface roughness, the thickness of the recast layer and the microstructure is very low..$^{9,19}$

\subsection{Effect of the cutting parameters on the recast-layer thicknesses}

The basic metallurgical effects that occur during the cutting with WEDM are the formation and width of the recast layer and/or the heat-affected region. Figure 3 shows a SEM photo obtained from the surface adjacent to a machined surface. When the image is examined, it is seen that three different regions formed after the cutting operation. At the very top, there is the recast layer. This layer developed because of the rapid cooling and re-solidification of the molten material with an auxiliary liquid-circulation pressure, without being removed from the cutting channel during the cutting with WEDM. The heat-affected region is the region where no melting occurs during the cutting, but the base metal undergoes microstructural changes under the influence of the resulting heat. At the very bottom, there is the base material.

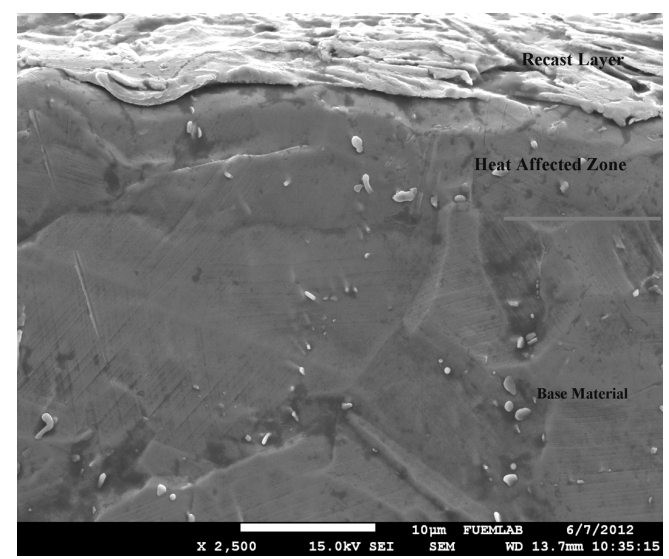

Figure 3: SEM of a kerf cross-section showing the RLT and HAZ Slika 3: SEM-prikaz prečnega preseka zareze, ki kaže $R L T$ in HAZ 


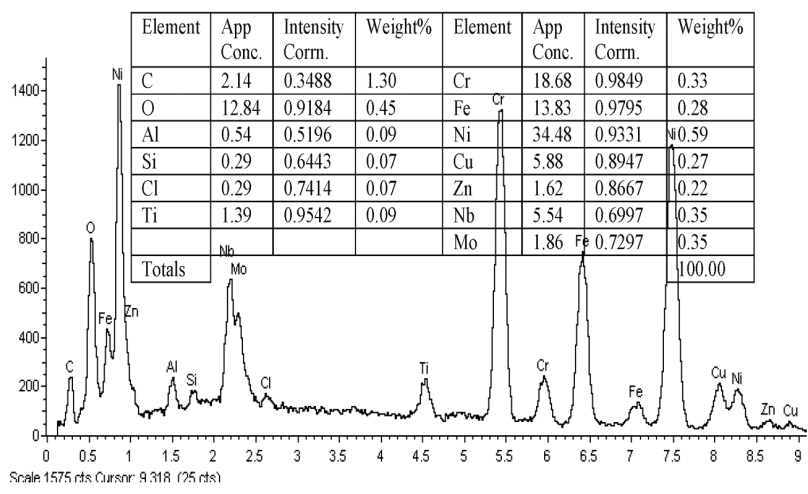

Figure 4: EDS analysis of the recast layer Slika 4: EDS-analiza pretaljene plasti

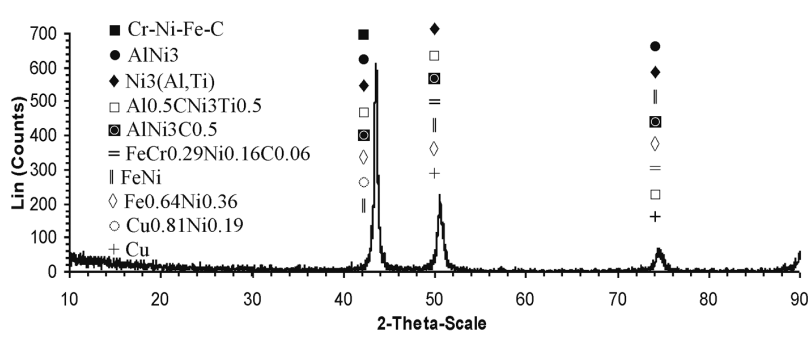

Figure 5: X-ray analysis of the recast layer Slika 5: Rentgenska analiza pretaljene plasti

EDS and XRD results for the recast layer are provided in Figures $\mathbf{4}$ and $\mathbf{5}$. When the analyses are evaluated, the results show that the recast layer is enriched with oxygen and carbon. This phenomenon was explained by T. R. Newton et al. ${ }^{20}$ to be the result of the electrolysis taking place in the dielectric liquid. In addition, the presence of copper and zinc compounds in the recast layer is evident. While Inconel 718 contains $0.08 \%$ of mass fractions of $\mathrm{Cu}$, the EDS results for the recast layer indicate that the density of $\mathrm{Cu}$ increases. Even though there is no $\mathrm{Zn}$ in the structure, the presence of this element in the recast layer indicates that these elements diffuse from the wire electrode into the workpiece, as reported in the previous studies. ${ }^{21}$

Table 4: Microhardness distribution through the cut surface section Tabela 4: Razporeditev mikrotrdote skozi prerezano področje na površini

\begin{tabular}{|l|c|c|c|c|c|c|c|c|c|}
\hline \multirow{2}{*}{$\begin{array}{l}\text { Measurement } \\
\text { region }\end{array}$} & \multicolumn{10}{|c|}{ Experiment number } \\
\cline { 2 - 12 } & 1 & 2 & 3 & 4 & 5 & 6 & 7 & 8 & 9 \\
\hline Base material & 418 & 410 & 408 & 416 & 420 & 416 & 413 & 406 & 410 \\
\hline Recast layer & 387 & 392 & 400 & 375 & 402 & 402 & 396 & 400 & 402 \\
\hline $\begin{array}{l}\text { Heat-affected } \\
\text { zone }\end{array}$ & 415 & 474 & 422 & 424 & 426 & 412 & 418 & 410 & 418 \\
\hline
\end{tabular}

Table 4 gives the average microhardness values for the three regions defined. While the hardness of the heat-affected region shows similarity to the base material, the microhardness of the recast layer shows a slight decrease when compared to the base material. The reason for this is assumed to be a decrease in the hardness of the recast layer, being a result of the dissolution of the $\gamma^{\prime}\left(\mathrm{N}_{3} \mathrm{Al}, \mathrm{Ti}\right)$ secondary phases and carbides back into the main matrix, after the heat treatment of the specimens. In their study, T. R. Newton et al. ${ }^{20}$ indicated that the hardness of the recast layer reduces due to the wire-electrical-discharge machining of the age-hardened Inconel 718 alloy. In their study, a reduced chromium density in the recast layer and the existence of $\mathrm{Cu}$ and $\mathrm{Zn}$ in this region cause the properties of the region to change.

Since the outermost recast layer is in direct contact with the environment, the determination of the thickness of this layer plays an important role when assessing the finish cut. Figure 6 shows the effects of the cutting parameters on the recast-layer thickness $(R L T)$. In addition, in Figure 7, SEM images show a variation in the $R L T$ depending on the experimental parameters. When these figures are analyzed, it is seen that while the effect of the circulation pressure on the recast layer is small, the effects of the current and the pulse duration are large. Under constant current conditions, the average RLT increases with the increasing pulse duration. Since the amount of heat transferred onto the surface of the workpiece increases with the increasing pulse duration, the amount of the material to be melted from the surface increases as well.

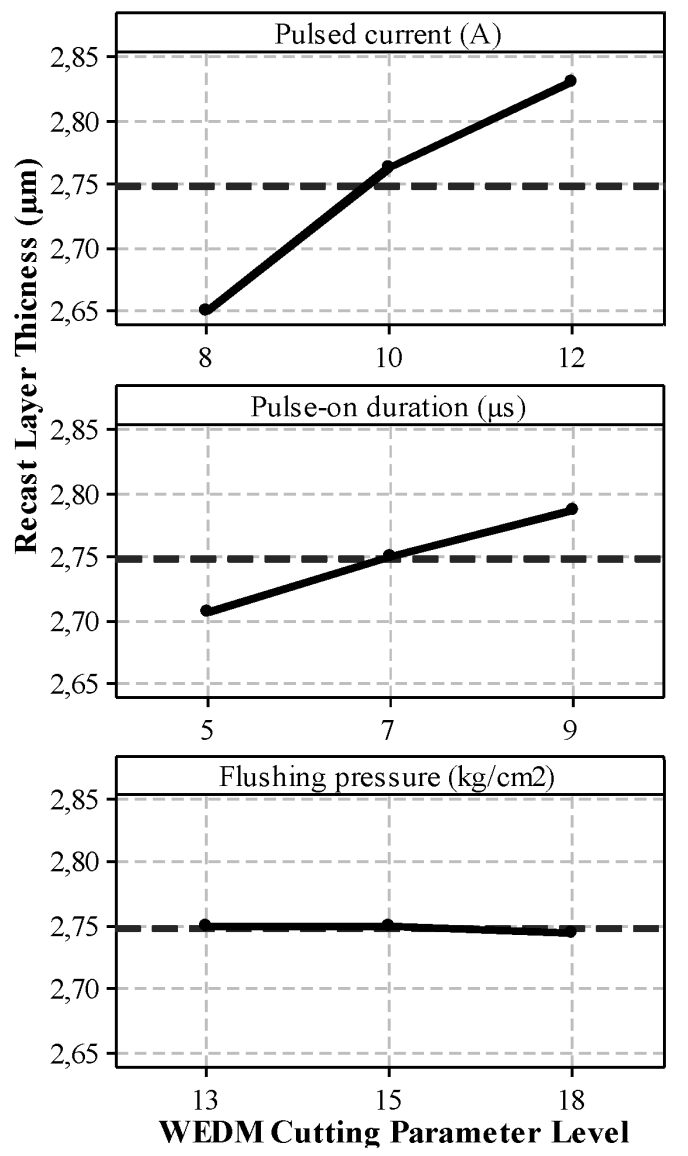

Figure 6: Main-effect plots of WEDM cutting factors for the RLT Slika 6: Diagrami glavnih vplivnih faktorjev pri WEDM rezanju na $R L T$ 


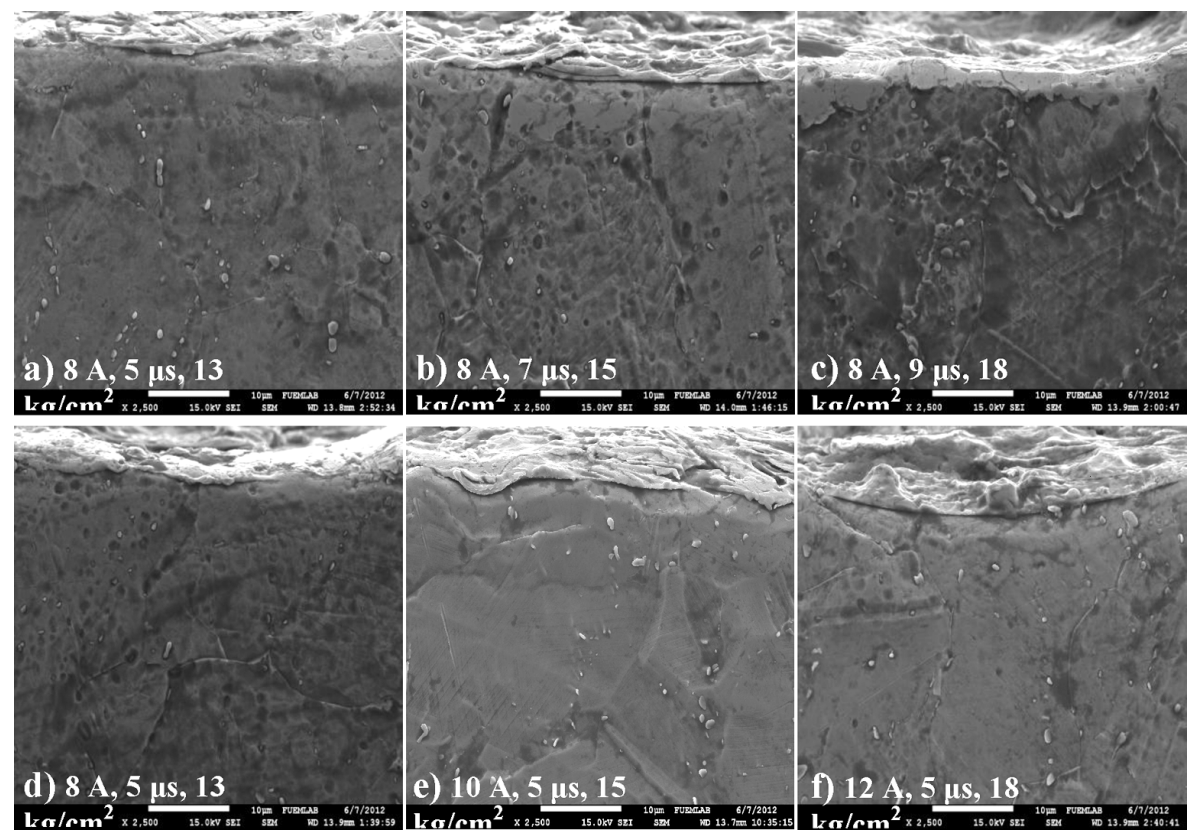

Figure 7: Cross-sectional SEM micrographs of a surface WEDM-processed under different machining conditions Slika 7: SEM-posnetki presekov z WEDM obdelane površine pri različnih pogojih obdelave

As the pulse duration increases, the isothermal curves of the material spread more into the sublayers and the amount of the heat spreading under the surface covers a large area. This, in turn, causes a large region to be influenced by the heat and the $R L T$ to increase. ${ }^{22}$ Moreover, the average $R L T$ increases considerably with increased current values under constant pulse-duration conditions. As the current increases, the discharge energy gets more intense. High discharge energy causes more material to melt. In parallel with the thickness of the melted material, the RLT increases as well. In their study, Kanlayasiri and Boonmung ${ }^{10}$ mentioned that in the cases where the current and pulse duration were high, the machined surface was rougher and thermal damages were deeper since the discharge energy acting on the workpiece surface was more intense. For this reason, they indicated that the current and pulse duration should be kept at low levels, but also that in the cases where these two parameters are kept at low levels, the duration and cost of the machining process increase.

\subsection{Effect of the cutting parameters on the surface roughness}

During wire-electrical-discharge machining, the discharge energy released with each discharge produces a very high amount of heat at the point where the spark hits the workpiece. This heat causes small pieces on the surface to melt and detach via vaporization. Spherical chips removed from the surface with each discharge change the machined surface into a crater structure. The surface morphology depends on the sizes of the craters that form due to the contact between the sparks and the surface. Therefore, the surface profile is a function of the current and pulse duration, determining the intensity of the applied sparks. ${ }^{23}$

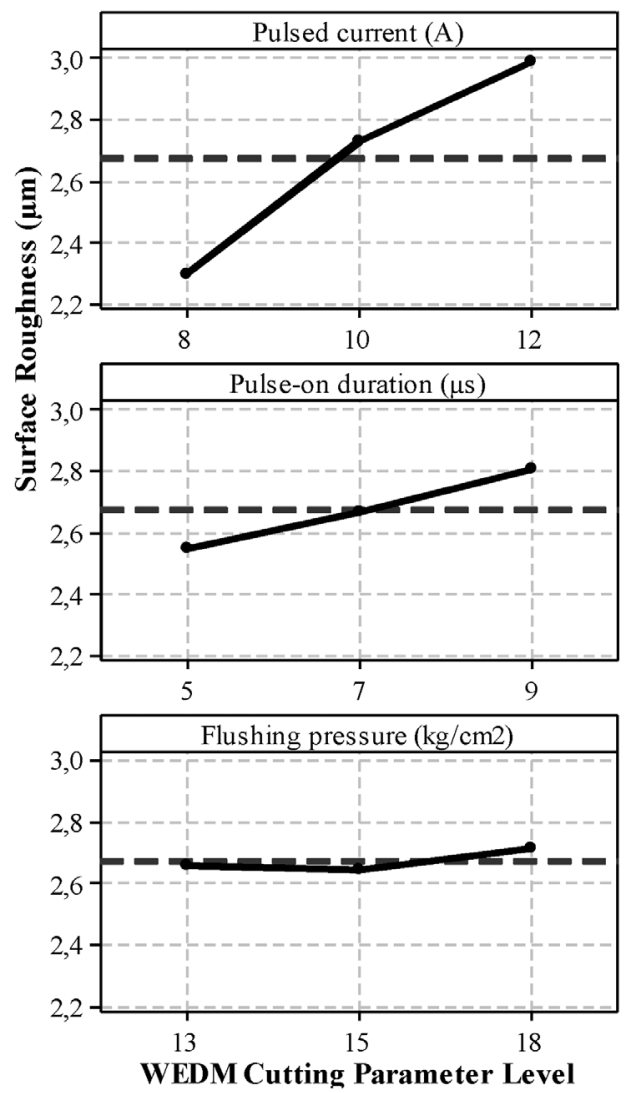

Figure 8: Main-effect plots of WEDM cutting factors for the surface roughness

Slika 8: Diagrami glavnih vplivnih faktorjev pri WEDM rezanju na hrapavost površine 


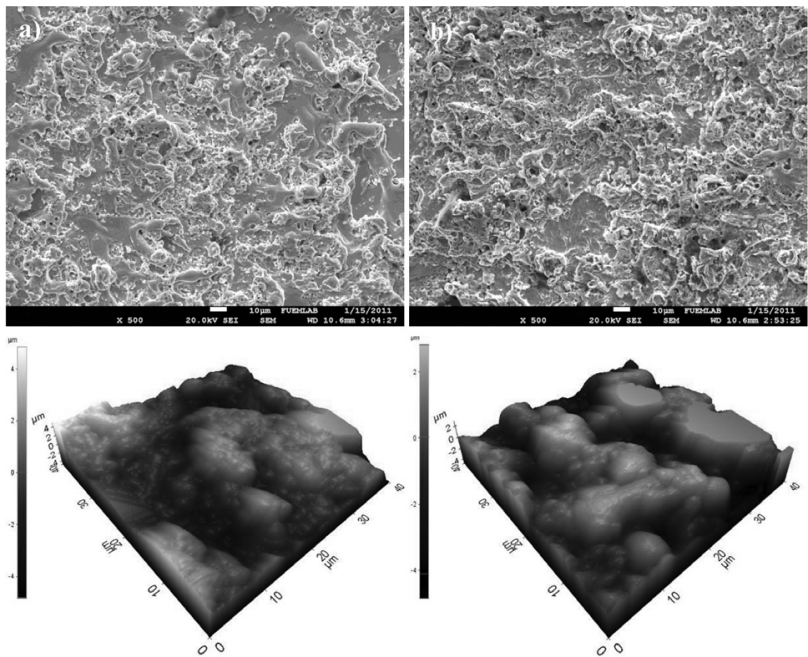

Figure 9: SEM and three-dimensional AFM images of the first and ninth experiments

Slika 9: SEM- in tridimenzionalni AFM-sliki prvega in devetega preizkusa

Figure 8 demonstrates the effects of the variables such as the current intensity, the pulse duration and the dielectric flushing pressure on the surface roughness, $R_{\mathrm{a}}$. The fact that the current intensity and pulse duration have large effects on the surface roughness is clearly seen on the graphs. If the current is low, the intensity of the sparks that hit the surface of the piece with each discharge is also lower. This leads to a smoother surface due to a better erosion effect. Additionally, the amount of heat transferred to the surface of a piece decreases with a shortening pulse duration; therefore, less metal is melted. Thus, with the craters being more superficial, the surface roughness decreases. ${ }^{23,24}$

The lowest surface roughness of $2.08 \mu \mathrm{m}$ was measured at the end of experiment no. 1, while the highest surface roughness of $3.01 \mu \mathrm{m}$ was measured at the end of experiment no. 9. In Figure 9, SEM and 3D AFM images of specimens 1 and 9 are shown. On the

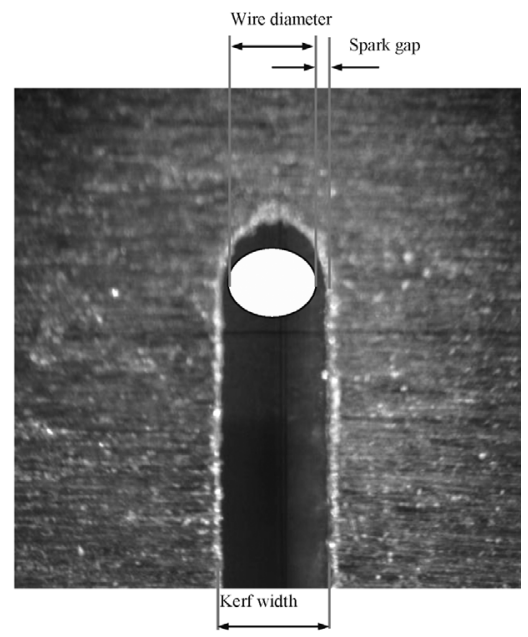

Figure 10: Schematic representation of the kerf width Slika 10: Shematičen prikaz širine zareze
AFM image, it is possible to see the maximum and minimum heights of the surface profile and hillocks and valleys. A higher roughness can be assessed on the basis of the values for the $Z$ depth of the AFM profile. When both figures are taken into account, it is observed that the surface-roughness values of the specimens show a tendency to decrease while all the cutting parameters decrease.

\subsection{Effect of the WEDM parameters on the kerf width}

Figure 10 shows a schematic representation of a kerf formed during wire-electrical-discharging. During wire-electrical-discharge machining, pieces are removed from the workpiece via melting as a result of the high temperature caused by spark discharges, occurring between the wire and the workpiece and the kerf occurs when these pieces are removed from the intermediate region with the liquid-circulation pressure. The kerf width varies depending on the parameters used during the machining. Alias et al. ${ }^{25}$ proved that as the feed ratio increases, the kerf width decreases and, as a result of the experiments, low feed ratios increased the kerf width. Somashekhar and Ramachandran ${ }^{26}$ did not recommend machining at high feed ratios as high feed rates increase the distortions in the kerf width. Tosun et al. ${ }^{27}$ demon-
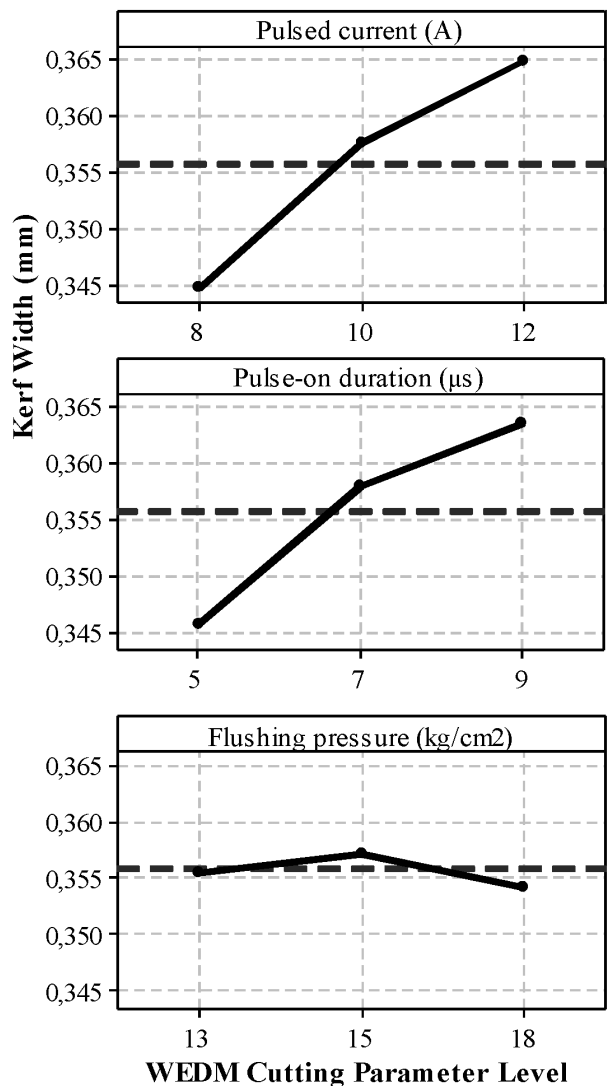

Figure 11: Main-effect plots of WEDM cutting factors for the kerf width

Slika 11: Diagrami glavnih vplivnih faktorjev pri WEDM rezanju na širino zareze 

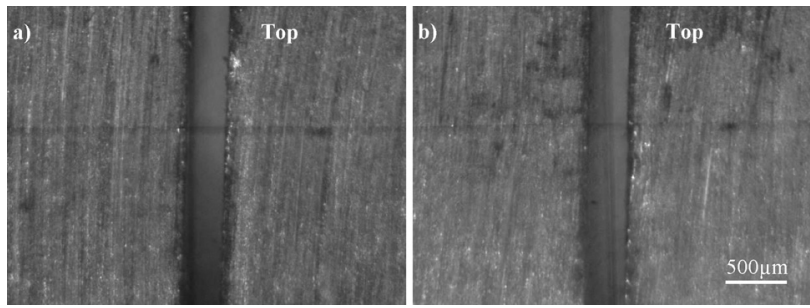

Figure 12: Light micrographs of the kerf width obtained at different cutting conditions: a) pulsed current $=8 \mathrm{~A}$, pulse-on duration $=5 \mu \mathrm{s}$, flushing pressure $\left.\left(\mathrm{kg} / \mathrm{cm}^{2}\right)=13, \mathrm{~b}\right)$ pulsed current $=12 \mathrm{~A}$, pulse-on duration $=9 \mu \mathrm{s}$, flushing pressure $\left(\mathrm{kg} / \mathrm{cm}^{2}\right)=15$

Slika 12: Svetlobna posnetka širine zareze, dobljena pri različnih pogojih rezanja: a) tok pulza $=8 \mathrm{~A}$, trajanje pulza $=5 \mu \mathrm{s}$, tlak splakovanja $\left.\left(\mathrm{kg} / \mathrm{cm}^{2}\right)=13, \mathrm{~b}\right)$ tok pulza $=12 \mathrm{~A}$, trajanje pulza $=9 \mu \mathrm{s}$, tlak splakovanja $\left(\mathrm{kg} / \mathrm{cm}^{2}\right)=15$

strated experimentally and mathematically that the open-circuit voltage and the pulse duration have a high influence on the kerf width and the material-lift ratio. They indicated that, for the kerf-width control, the voltage is three times more effective than the pulse duration.

Graphs showing the effects of the experimental parameters on the kerf width are given in Figure 11. As it can be seen, the average top kerf width varies dramatically, depending on the variations in the current intensity and pulse duration. An increase in the pulse duration causes a longer-term spark shock and, accordingly, the removal of more chips from the surface. As a result, depending on the amount of the chips removed from the cutting zone, the kerf width increases. Similarly, an

Table 5: Experimental results

Tabela 5: Rezultati eksperimentov

\begin{tabular}{|c|c|c|c|}
\hline Exp. No & $R L T(\mu \mathrm{m})$ & $\begin{array}{c}\text { Surface } \\
\text { roughness } \\
(\mu \mathrm{m})\end{array}$ & $\begin{array}{c}\text { Kerf width } \\
(\mathrm{mm})\end{array}$ \\
\hline 1 & 2.61 & 2.08 & 0.335 \\
\hline 2 & 2.65 & 2.31 & 0.348 \\
\hline 3 & 2.69 & 2.51 & 0.351 \\
\hline 4 & 2.73 & 2.61 & 0.349 \\
\hline 5 & 2.76 & 2.69 & 0.359 \\
\hline 6 & 2.80 & 2.89 & 0.365 \\
\hline 7 & 2.78 & 2.95 & 0.353 \\
\hline 8 & 2.84 & 3.00 & 0.367 \\
\hline 9 & 2.87 & 3.01 & 0.375 \\
\hline
\end{tabular}

Table 6: Results of ANOVA for the recast-layer thickness Tabela 6: Rezultati ANOVA za debelino pretaljene plasti

\begin{tabular}{|c|c|c|c|c|c|}
\hline $\begin{array}{c}\text { WEDM cutting } \\
\text { parameter }\end{array}$ & $\begin{array}{c}\text { Degree of } \\
\text { freedom } \\
(\mathrm{d} f)\end{array}$ & $\begin{array}{c}\text { Sum of } \\
\text { square } \\
\left(S S_{A}\right)\end{array}$ & $\begin{array}{c}\text { Mean } \\
\text { square }\end{array}$ & $F$ & $P(\%)$ \\
\hline $\begin{array}{c}\text { Pulsed current } \\
(\mathrm{A})\end{array}$ & 2 & 0.04969 & 0.02484 & 15.11 & 83.65 \\
\hline $\begin{array}{c}\text { Pulse-on } \\
\text { duration }(\mu \mathrm{s})\end{array}$ & 2 & 0.00962 & 0.00481 & 0.58 & 16.16 \\
\hline $\begin{array}{c}\text { Flushing } \\
\text { pressure }(\mathrm{MPa})\end{array}$ & 2 & 0.00008 & 0.00004 & 0.00 & 0.15 \\
\hline Error & - & - & - & - & 0.04 \\
\hline Total & 6 & 0.05939 & - & - & 100 \\
\hline
\end{tabular}

increase in the kerf width was observed with the increasing current intensity. If the current is low, the intensity of the sparks that hit the surface of the piece with each discharge is also low. High-intensity sparks lead to the widening of the kerf by creating a deeper corrosion effect on the surface.

Figure 12 gives images of specimens 1 and 9 where the lowest and highest kerf widths were obtained, respectively. Under the conditions of experiment 1 where the current intensity (8 A), pulse duration and liquid-circulation pressure $(5 \mu \mathrm{s}, 1.27 \mathrm{MPa})$ were at their lowest values, the kerf width was measured as $0.335 \mathrm{~mm}$. Under the conditions of experiment 9 where the current intensity, pulse duration and liquid-circulation pressure (12 A, $9 \mu \mathrm{s}, 1.47 \mathrm{MPa}$ ) were at their highest values, the kerf width was measured as $0.375 \mathrm{~mm}$.

\section{STATISTICAL ANALYSIS OF THE EXPERIMENTAL RESULTS}

In this study, an analysis of the WEDM experimental results was performed using the analysis of variance (ANOVA) method. This method is used to statistically examine the impacts of the machining parameters on the operational performance. The experiment numbers and the measurements obtained at the end of the experiments are collectively presented in Table 5. The ANOVA results for the $R L T$, surface roughness and kerf width in the case of WEDM can be seen in Tables 6 to 8, respectively. According to the results in Table 6, the current intensity has a major effect of as much as $84 \%$ on the

Table 7: Results of ANOVA for the surface roughness

Tabela 7: Rezultati ANOVA za hrapavost površine

\begin{tabular}{|c|c|c|c|c|c|}
\hline $\begin{array}{c}\text { WEDM cutting } \\
\text { parameter }\end{array}$ & $\begin{array}{c}\text { Degree of } \\
\text { freedom } \\
(\mathrm{d} f)\end{array}$ & $\begin{array}{c}\text { Sum of } \\
\text { square } \\
\left(S S_{A}\right)\end{array}$ & $\begin{array}{c}\text { Mean } \\
\text { square }\end{array}$ & $F$ & $P(\%)$ \\
\hline $\begin{array}{c}\text { Pulsed current } \\
(\mathrm{A})\end{array}$ & 2 & 8.154 & 4.077 & 13.83 & 82.17 \\
\hline $\begin{array}{c}\text { Pulse-on } \\
\text { duration }(\mu \mathrm{s})\end{array}$ & 2 & 1.21 & 0.60 & 0.42 & 12.18 \\
\hline $\begin{array}{c}\text { Flushing } \\
\text { pressure (MPa) }\end{array}$ & 2 & 0.16 & 0.08 & 0.05 & 1.57 \\
\hline Error & - & - & - & - & 4.08 \\
\hline Total & 6 & 9.524 & - & - & 100 \\
\hline
\end{tabular}

Table 8: Results of ANOVA for the kerf width

Tabela 8: Rezultati ANOVA za širino reza

\begin{tabular}{|c|c|c|c|c|c|}
\hline $\begin{array}{c}\text { WEDM cutting } \\
\text { parameter }\end{array}$ & $\begin{array}{c}\text { Degree of } \\
\text { freedom } \\
(\mathrm{d} f)\end{array}$ & $\begin{array}{c}\text { Sum of } \\
\text { square } \\
\left(S S_{A}\right)\end{array}$ & $\begin{array}{c}\text { Mean } \\
\text { square }\end{array}$ & $F$ & $P(\%)$ \\
\hline $\begin{array}{c}\text { Pulsed current } \\
(\mathrm{A})\end{array}$ & 2 & 0.000636 & 0.000318 & 3.65 & 54.87 \\
\hline $\begin{array}{c}\text { Pulse-on } \\
\text { duration }(\mu \mathrm{s})\end{array}$ & 2 & 0.000508 & 0.000254 & 2.34 & 43.83 \\
\hline $\begin{array}{c}\text { Flushing } \\
\text { pressure }(\mathrm{MPa})\end{array}$ & 2 & 0.000014 & 0.0000074 & 0.04 & 1.17 \\
\hline Error & - & - & - & - & 0.13 \\
\hline Total & 6 & 0.05939 & - & - & 100 \\
\hline
\end{tabular}


$R L T$. The effect of the pulse duration on the RLT is $16 \%$, whereas the liquid-circulation pressure has no effect on the RLT. Similarly, Tables $\mathbf{7}$ and $\mathbf{8}$ clearly show that the current intensity has a much larger effect on the surface roughness and kerf width than the pulse duration.

\section{MATHEMATICAL MODELING OF THE EXPERIMENTAL RESULTS}

In this study, mathematical modeling of the $R L T$, surface roughness and kerf width were performed by employing the multiple-linear-regression method on the results of the cutting experiments with WEDM. In addition, the appropriateness of the models obtained with the method of regression was investigated with ANOVA. Regression models with dependent parameters of the current intensity $\left(I_{\mathrm{p}}\right)$, pulse duration $\left(T_{\mathrm{on}}\right)$ and liquid-circulation pressure $(P S)$, and control parameters of the recast-layer thickness $(R L T)$, surface roughness $\left(R_{\mathrm{a}}\right)$ and kerf width $\left(K_{\mathrm{w}}\right)$ are expressed as follows:

Recast-layer thickness

$$
R L T=a_{0}+a_{1} \times I_{\mathrm{P}}+a_{2} \times T_{\text {on }}-a_{3} \times P S
$$

Surface roughness

$$
R_{\mathrm{a}}=a_{0}+a_{1} \times I_{\mathrm{P}}+a_{2} \times T_{\text {on }}+a_{3} \times P s
$$

Kerf width

$$
K_{\mathrm{w}}=a_{0}+a_{1} \times I_{\mathrm{P}}+a_{2} \times T_{\text {on }}-a_{3} \times P s
$$

The regression and correlation coefficients obtained are presented collectively in Table $\mathbf{9}$. When these coefficients are substituted into the equations, the mathematical models of the recast-layer thickness $(R L T)$, surface roughness $\left(R_{\mathrm{a}}\right)$ and kerf width $\left(K_{\mathrm{w}}\right)$ are obtained as:

$$
\begin{gathered}
R L T=2.18+0.0450 \times I_{\mathrm{P}}+0.0200 \times T_{\text {on }}- \\
-0.00140 \times P s \\
R_{\mathrm{a}}=0.307+0.172 \times I_{\mathrm{P}}+0.0642 \times T_{\text {on }}+ \\
+0.0130 \times P s \\
K_{\mathrm{w}}=0.278+0.00508 \times I_{\mathrm{P}}+0.00450 \times T_{\text {on }}- \\
-0.000325 \times P s
\end{gathered}
$$

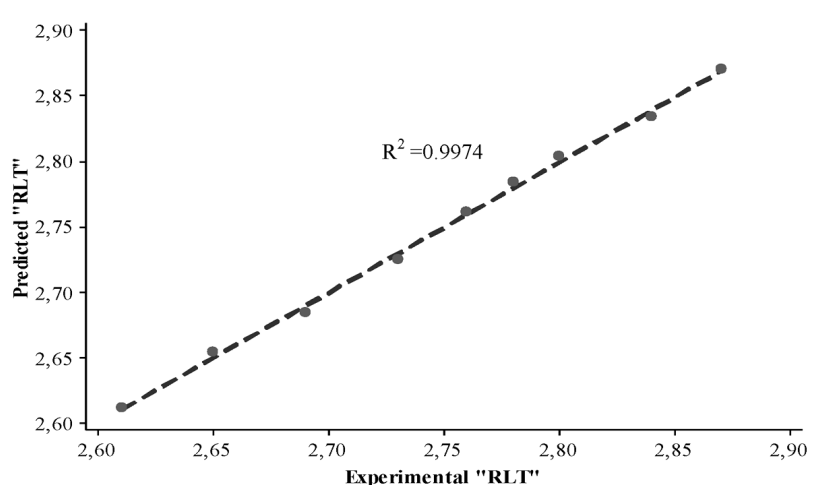

Figure 13: Comparison of experimental and predicted recast-layer thickness values

Slika 13: Primerjava eksperimentalno določene in napovedane debeline pretaljenega sloja

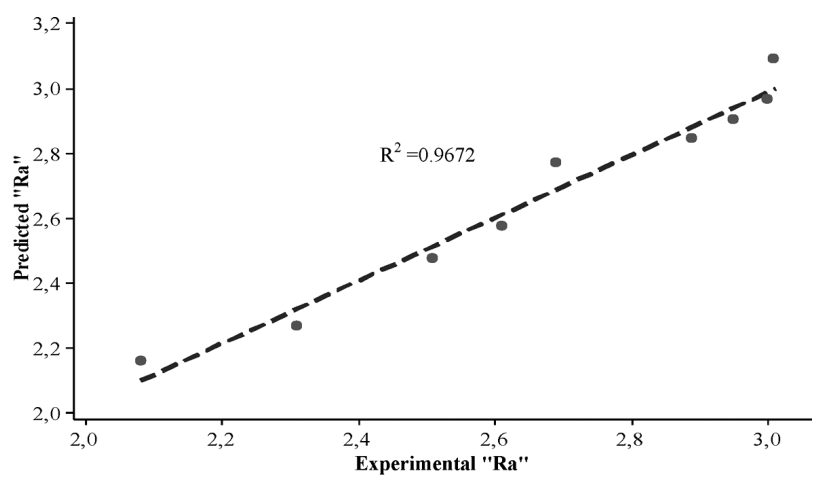

Figure 14: Comparison of experimental and predicted surface-roughness values

Slika 14: Primerjava eksperimentalno določene in napovedane hrapavosti površine

The correlation coefficients of the models from Table 9 show that the models that are quite appropriate. Experimental values of the recast-layer thickness $(R L T)$, surface roughness $\left(R_{\mathrm{a}}\right)$ and kerf width $\left(K_{\mathrm{w}}\right)$ are given in Table 10 along with their predicted values calculated with the obtained mathematical models.

Table 9: Regression and correlation coefficients Tabela 9: Regresijski in korelacijski koeficienti

\begin{tabular}{|c|c|c|c|c|c|}
\hline & $\begin{array}{c}\text { Regression } \\
\text { coefficients }\end{array}$ & \multicolumn{4}{|c|}{ Correlation coefficients $(r)$} \\
\hline & $a_{0}$ & $a_{1}$ & $a_{2}$ & $a_{3}$ & \\
\hline $\begin{array}{c}\text { Recast-layer } \\
\text { thickness }\end{array}$ & 2.18 & 0.0450 & 0.0200 & 0.00140 & $98.1 \%$ \\
\hline $\begin{array}{c}\text { Surface } \\
\text { roughness }\end{array}$ & 0.307 & 0.172 & 0.0642 & 0.0130 & $97.8 \%$ \\
\hline Kerf width & 0.278 & 0.00508 & 0.00450 & 0.000325 & $95.9 \%$ \\
\hline
\end{tabular}

Figures 13 to $\mathbf{1 5}$ show graphs of these values in their respective order. As it is seen on the figures, the experimental and numerical values show distributions quite close to the regression lines.

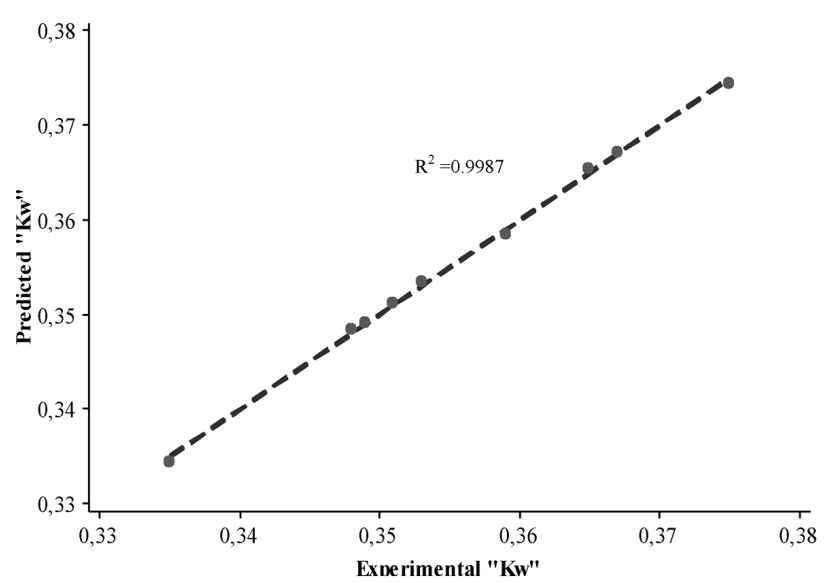

Figure 15: Comparison of experimental and predicted kerf-width values

Slika 15: Primerjava eksperimentalno določene in napovedane širine zareze 
Table 10: Estimated values and calculations obtained with mathematical models Tabela 10: Določene in z dobljenim matematičnim modelom izračunane vrednosti

\begin{tabular}{|c|c|c|c|c|c|c|}
\hline \multirow{2}{*}{ Exp. No } & \multirow{2}{*}{$\begin{array}{c}\text { Recast-layer } \\
\text { thickness } \\
\text { Experimental } \\
R L T\end{array}$} & \multirow{2}{*}{\begin{tabular}{|c|} 
Surface roughness \\
Estimated \\
$R L T$
\end{tabular}} & \multicolumn{4}{|c|}{ Kerf width } \\
\hline & & & $\begin{array}{c}\text { Experimental } \\
R_{\mathrm{a}} \\
\end{array}$ & $\begin{array}{c}\text { Estimated } \\
R_{\mathrm{a}} \\
\end{array}$ & $\begin{array}{c}\text { Experimental } \\
K_{\mathrm{t}}\end{array}$ & $\begin{array}{c}\text { Estimated } \\
K_{\mathrm{t}} \\
\end{array}$ \\
\hline 1 & 2.61 & 2.61111 & 2.08 & 2.15889 & 0.335 & 0.334444 \\
\hline 2 & 2.65 & 2.65444 & 2.31 & 2.26556 & 0.348 & 0.348444 \\
\hline 3 & 2.69 & 2.68444 & 2.51 & 2.47556 & 0.351 & 0.351111 \\
\hline 4 & 2.73 & 2.72444 & 2.61 & 2.57556 & 0.349 & 0.349111 \\
\hline 5 & 2.76 & 2.76111 & 2.69 & 2.76889 & 0.359 & 0.358444 \\
\hline 6 & 2.80 & 2.80444 & 2.89 & 2.84556 & 0.365 & 0.365444 \\
\hline 7 & 2.78 & 2.78444 & 2.95 & 2.90556 & 0.353 & 0.353444 \\
\hline 8 & 2.84 & 2.83444 & 3.00 & 2.96556 & 0.367 & 0.367111 \\
\hline 9 & 2.87 & 2.87111 & 3.01 & 3.08889 & 0.375 & 0.374444 \\
\hline
\end{tabular}

\section{CONCLUSIONS}

Based on the conducted research and investigations, the following conclusions can be drawn:

1. In the WEDM cutting process, the liquid-circulation pressure has little effect on the recast-layer thickness, surface roughness and kerf width, whereas the current and pulse duration are the most important parameters determining the quality of a cut. The highest quality cut was obtained with experiment 1 where the current and pulse duration were at their lowest values.

2. Considering the results of ANOVA, the intensity of the current was statistically found to have a larger effect on the surface roughness, kerf width and $R L T$ than the pulse duration.

3. Taking the correlation coefficients into account, the obtained linear-regression models yield estimates with appropriate error rates. These results, in turn, show that the obtained models are appropriate.

\section{REFERENCES}

${ }^{1}$ A. Sharman, R. C. Dewes, D. K. Aspinwall, Journal of Materials Processing Technology, 118 (2001), 29-35, doi:10.1016/S0924-0136 (01)00855-X

${ }^{2}$ A. Hasçalik, M. Ay, Optics \& Laser Technology, 48 (2013), 554-564, doi:10.1016/j.optlastec.2012.11.003

${ }^{3}$ M. Ay, U. Çaydaş, A. Hasçalik, Materials and Manufacturing Processes, 25 (2010), 1-6, doi:10.1080/10426914.2010.502953

${ }^{4}$ E. O. Ezugwu, International Journal of Machine Tools \& Manufacture, 45 (2005), 1353-1367, doi:10.1016/j.ijmachtools.2005. 02.003

${ }^{5}$ D. Dudzinski, A. Devillez, A. Moufki, D. Larrouquežre, V. Zerrouki, J. Vigneau, International Journal of Machine Tools \& Manufacture, 44 (2004), 439-456, doi:10.1016/S0890-6955(03)00159-7

${ }^{6}$ M. Ay, U. Çaydaş, A. Hasçalik, International Journal of Advanced Manufacturing Technology, 44 (2012), 439-456, doi:10.1007/ s00170-012-4385-8

${ }^{7}$ D. Scot, S. Boyina, K. P. Rajurkar, Int. J. Prod. Res., 29 (1991), 2189-2207, doi:10.1080/00207549108948078

${ }^{8}$ P. Bleys, J. P. Kruth, B. Lauwers, B. Schacht, V. Balasubramanian, L. Froyen, J. Van Humbeeck, Advanced Engineering Materials, 8 (2006), 15-25, doi:10.1002/adem.200500211
${ }^{9}$ A. Hasçalik, U. Çaydaş, Journal of Materials Processing Technology, 148 (2004), 362-367, doi:10.1016/j.jmatprotec.2004.02.048

${ }^{10}$ K. Kanlayasiri, S. Boonmung, Journal of Materials Processing Technology, 187-188 (2007), 26-29, doi:10.1016/j.jmatprotec.2006. 11.220

${ }^{11}$ S. Kuriakose, M. S. Shunmugam, Materials Letters, 58 (2004), 2231-2237, doi:10.1016/j.matlet.2004.01.037

${ }^{12}$ M. İ. Gökler, A. M. Ozanözgü, International Journal of Machine Tools \& Manufacture, 40 (2000), 1831-1848, doi:10.1016/S08906955(00)00035-3

${ }^{13}$ S. F. Miller, C. C. Kao, A. J. Shih, J. Qu, International Journal of Machine Tools \& Manufacture, 45 (2005), 1717-1725, doi:10.1016/ j.ijmachtools.2005.03.003

${ }^{14}$ R. Ramakrishnan, L. Karunamoorty, Journal of Materials Processing Technology, 207 (2008), 343-349, doi:10.1016/j.jmatprotec.2008. 06.040

${ }^{15}$ S. H. Kang, D. E. Kim, KSME International Journal, 17 (2003), 1475-1484, doi:10.1007/BF02982327

${ }^{16}$ C. Y. Bai, C. H. Koo, C. C. Wang, Materials Transactions, 45 (2004), 2878-2885, doi:10.2320/matertrans.45.2878

${ }^{17}$ D. K. Aspinwall, S. L. Soo, A. E. Berrisford, G. Walder, CIRP Annals, 57 (2008) 1, 187-190, doi:10.1016/j.cirp.2008.03.054

${ }^{18}$ M. S. Hewidy, T. A. El-Taweel, M. F. El-Safty, Journal of Materials Processing Technology, 169 (2005), 328-336, doi:10.1016/ j.jmatprotec.2005.04.078

${ }^{19}$ Y. S. Liao, J. T. Huang, H. C. Su, Journal of Materials Processing Technology, 71 (1997), 487-493, doi:10.1016/S0924-0136(97) 00117-9

${ }^{20}$ T. R. Newton, S. N. Melkote, T. R. Watkins, R. M. Trejo, L. Reister, Materials Science and Engineering A, 513-514 (2009), 208-215, doi:10.1016/j.msea.2009.01.061

${ }^{21}$ J. T. Huang, Y. S. Liao, W. J. Hsue, Journal of Materials Processing Technology, 87 (1999), 69-81, doi:10.1016/S0924-0136(98)00334-3

${ }^{22} \mathrm{U}$. Çaydaş, Investigation of the Machinability of Ti6Al4V alloy by electrical discharge and electrochemical machining processes, $\mathrm{PhD}$ Thesis, Firat University Graduate School of Natural and Applied Sciences, 2008, 95-98

${ }^{23}$ Y. H. Guu, K. Hou, Materials Science and Engineering A, 466 (2007), 61-67, doi:10.1016/j.msea.2007.02.035

${ }^{24}$ H. Ramasawmy, L. Blunt, K. P. Rajurkar, Precision Engineering, 29 (2005), 479-490, doi:10.1016/j.precisioneng.2005.02.001

${ }^{25}$ A. Alias, B. Abdullah, N. M. Abbas, Procedia Engineering, 41 (2012), 1806-1811, doi:10.1016/j.proeng.2012.07.387

${ }^{26}$ K. P. Somashekhar, N. Ramachandran, J. Mathew, Int. J. Adv. Manuf. Technol., 51 (2010), 611-626, doi:10.1007/s00170-0102645-z

${ }^{27}$ N. Tosun, C. Cogun, A. Gnan, Machining Science and Technology, 7 (2003), 209-219, doi:10.1081/MST-120022778 